\title{
My summer reading
}

Does anyone, now that the publishing industry seems to have become another platform for sleb publicity, still read books?

If you do, you'll know that some of the best of them are being published on the other side of the Atlantic. The New York Review of Books, a left-liberal fortnightly current affairs digest and book review which is read not just by the cultured but (as its ad claims) the powerful, is also an imprint: its lower-case initials now decorate the monochrome spines of several hundred trade paperbacks. The Classics list offers fiction and non-fiction from all ages and around the world, such as Robert Burton's great remedial study The Anatomy of Melancholy (1632), one of the great works of 'sick lit', Daniel Schreber's Memoirs of my Nervous Illness (1903), classic collections of stories by Chekhov, Maupassant, and Cesare Pavese, Simenon's darker 'psychological' novels, as well as Elizabeth David's cookbooks, one or two poetry collections, and unclassifiable but brilliant memoirs such as JR Ackerley's My Dog Tulip.

The NYRB also publish Patrick Leigh Fermor's A Time to Keep Silence, a series of observations on what it takes to hold a monkish vow of silence for years on end and the inspiration, if I'm not mistaken, for an unhurried, one-man film on the life of the brothers of the Grande Chartreuse, Philip Gröning's Into Great Silence (2006), a nearly silent film which took him 6 months to shoot while living with the monks. The NYRB also publish a version of Dante's The Divine Comedy as well as the commentary on its author by the great German critic Erich Auerbach, who, chased from his professorship by the Nazis, spent the war years in Istanbul writing a unified theory of representation based on the great works of Western literature. The Private Memoirs and Confessions of a Justified Sinner is also on NYRB's list, that perversely Scottish novel rescued from oblivion by the attentions of André Gide, along with collections of brilliantly cutting aphorisms by two writers active at the time of the French revolution (Georg Christoph Lichtenberg and Joseph Joubert, the latter translated by Paul Auster).

Last year, I purchased the slightly creepy Novels in Three Lines by the anarchist and journalist Félix Féneon (1861-1944): these are lurid fillers first published in the Paris newspaper Le Matin in 1906, and dutifully cut out and preserved in her scrapbook by his mistress. Fénéon displayed no interest at all in publishing them in book form during his lifetime, despite his other literary activities. In more than a thousand teasingly clipped causalities, adultery, murder, and revenge are stripped down to the bare bones. The mother-in-law joke? 'Scheid, of Dunkirk, fired three times at his wife. Since he missed every shot, he decided to aim at his mother-in-law, and connected.' The holy drinker's epitaph? 'There is no longer a God even for drunkards. Kersilie, of St. Germain, who had mistaken the window for the door, is dead.' Domestic calamity? 'Lit by her son, 5 , a signal flare burst under the skirts of Mme. Roger, of Clichy; damages were considerable.' Fénéon gives an entirely new sense to the phrase 'mentioned in despatches': these texts nail their subjects.

My favourite NYRB book is another translation from the French, a first-hand account of a journey to the Arctic by a young man from Togo - and what may be one of the most curious books of 'travel literature' ever published. Tété-Michel Kpomassie (1941) first saw a book on the Eskimos in his local store in Lomé, and was seized with the idea of going to live among them. It took him 6 years to work his way to Europe, and another two to get to Greenland. His book was published in French in 1981, when Paris was more interested in exotic societies than it is now. Kpomassie was an exotic freak from the moment he disembarked in Julianehåb, standing about 8 inches taller than most Inuits. None of the Greenlanders had ever seen an African before. While he enjoys their hospitality (no door is ever locked and he is poor) he is dismayed at the drunkenness and promiscuity. 'I wanted to live with seal hunters, ride in a sledge, sleep in an igloo!' When pack ice prevents him getting to Thule, he winters over in Upernavik, in one of the few authentic Inuit buildings left in Greenland. Incongruously, its turf construction reminds him of an African mud-walled hut. The months he spends with the owner, Robert Mattaaq and his family, are the most interesting in the book. Kpomassie must be one of the very few people qualified to draw a comparison between whale and lion hunting: both traditional societies adopt the same psychological attitude to their prey. Hunting is a kind of sacred crime that demands the animal's consent before it is killed and elaborate expiatory rites once it is actually dead.

Most obligingly, NYRB are open to suggestions for future publications. You can write to them and suggest a title you believe has been unfairly neglected or simply too long out-of-print. That, I suppose, is one of the great things about American society. Having lived with the market since its inception, it knows how to milk the antidote from the poison. For as Chesterton wrote in Lunacy and Letters, following the letter of Burton' recipes, 'there is probably many an old collector whose friends and relations say that he is mad on Elzevirs, when as a matter of fact it is the Elzevirs that keep him sane. Without them he would drift into souldestroying idleness and hypochondria; but the drowsy regularity of his notes and calculations teaches something of the same lesson as the swing of the smith's hammer of the plodding of the ploughman's horses, the lessons of the ancient commonsense of things'.

http://www.nybooks.com/nyrb/

\section{lain Bamforth}

DOI: 10.3399/bjgp08X342507 